Molecules 2005, 10, 1358-1363

\title{
molecules
}

ISSN 1420-3049

http://www.mdpi.org

\section{Urea- Hydrogen Peroxide (UHP) Oxidation of Thiols to the Corresponding Disulfides Promoted by Maleic Anhydride as Mediator}

\author{
Bahador Karami $^{1, *}$, M. Montazerozohori ${ }^{1}$ and M. H. Habibi ${ }^{2}$ \\ ${ }^{1}$ Department of Chemistry, Yasouj University, Yasouj 75914-353, Iran \\ ${ }^{2}$ Department of Chemistry, Isfahan University, Isfahan 81745-117, Iran \\ * Author to whom correspondence should be addressed. E-mail: karami@mail.yu.ac.ir
}

Received: 12 July 2005; in revised form: 21 July 2005 / Accepted: 22 July 2005 / Published: 31 October 2005

\begin{abstract}
Urea-hydrogen peroxide (UHP) was used in the presence of maleic anhydride as mediator in a simple and convenient method for the oxidation in high yield of some thiols to the corresponding disulfides. Peroxymaleic acid formed in situ from the reaction of UHP with maleic anhydride has a key role in this oxidation. Performance of the reaction in various solvents showed that methanol was the solvent of choice at $0{ }^{\circ} \mathrm{C}$. The products were isolated by simple filtration on silica gel.
\end{abstract}

Keywords: UHP; thiols; disulfides; oxidation.

\section{Introduction}

Conversion of thiols to the related disulfides is of interest both from a biological and chemical point of view $[1,2]$. Disulfides, especially diaryl disulfides, are very commonly used as electrophiles in the sulfenylation of enolates and other anions [3-4]. Oxidative S-S coupling of thiols can be done under biological conditions in the presence of oxidants such as flavins and cytochromes [5]. In the laboratory thiols can be oxidized to corresponding disulfides by several oxidants such as: redox dyes [5], nitro compounds [6], diazocompounds [7], sulfoxides [8], halogens [9], 2-polyvinylpyridine/bromine complex [10], $\mathrm{H}_{2} \mathrm{O}_{2}$ [11], $\mathrm{KMnO}_{4} / \mathrm{CuSO}_{4}$ [12], DMSO/ $\mathrm{I}_{2}$ [1a,13], sodium perborate [14] and by electrochemical methods [15]. Due to the synthetic importance of disulfides, there has been an ongoing interest in new chemical and biotic methods [16-18]. Some of the methods mentioned 
suffer from a variety of disadvantages such as long reaction times, unavailability and/or toxicity of the reagents and difficult isolation of products. As a result the introduction of readily available, safe and stable reagents for the oxidation of thiols to disulfides is still a necessity. Over the past few years, several reports have appeared on the use of urea-hydrogen peroxide (UHP) in oxidations, namely for the conversion of amines to nitroalkanes [19], Baeyer-Villiger oxidations of ketones to lactones [20], oxidations of sulfides to sulfones [21], oxidation of aromatic aldehydes [22], aromatization of 1,4dihydro-pyridines [23], epoxidation of alkenes and conversion of pyridine to pyridine $N$-oxides [24]. In continuation of our studies on applications of UHP as a replacement for $\mathrm{H}_{2} \mathrm{O}_{2}$ [25], we were interested in using the UHP/maleic anhydride system for the conversion of thiols to disulfides.

\section{Results and Discussion}

Hydrogen peroxide is the most common reagent for oxidation of organic compounds, especially thiols, but it has several problems such as instability of the reagent itself and overoxidation of thiols to sulfonic acids as well as the desired disulfides. The use of hydrogen peroxide adducts is a convenient strategy to control $\mathrm{H}_{2} \mathrm{O}_{2}$ oxidation reactions. In general, hydrogen peroxide adducts are not able to oxidize organic compounds by themselves, therefore introduction of an inorganic catalyst or organic mediator for active oxygen transfer of these adducts is a necessity in oxidation systems where they are used. Among these adducts urea-hydrogen peroxide is an inexpensive, stable, mild and easy to handle source of pure $\mathrm{H}_{2} \mathrm{O}_{2}$ [25]. Considering this fact the potential use of a UHP containing system for the oxidation of thiols was investigated. We found that 4-methylthiophenol was oxidized to 4,4'-dimethyldiphenyldisulfide by UHP under mild conditions in the presence of maleic anhydride as mediator. A control reaction for the oxidation of 4-methylthiophenol in the absence of maleic anhydride was performed and the results showed that the reaction did not take place to any significant extent, therefore we conclude that maleic anhydride was need for efficient progress of the reaction.

To examine the effect of the solvent, the oxidation of 4-methylthiophenol was performed in different solvents. As shown in Table 1, methanol was the best solvent under the reaction conditions, apparently because of good solubility of starting materials, although the reaction was also completed in acetonitrile but in longer period.

Table 1. Solvent effects on oxidative coupling of 4-methylthiophenol with $\mathrm{UHP} /$ maleic anhydride at $0^{\circ} \mathrm{C}$

\begin{tabular}{c|cc}
\hline \multirow{2}{*}{ Solvent } & \multicolumn{2}{c}{$\begin{array}{c}\text { Completion time of reaction [min] } \\
\mathbf{0}^{\mathbf{0}} \mathbf{C}\end{array}$} \\
\hline $\mathrm{CH}_{2} \mathrm{Cl}_{2}$ & $120^{\mathrm{a}}$ & $120^{\mathrm{a}}$ \\
$\mathrm{CHCl}_{3}$ & $140^{\mathrm{a}}$ & $140^{\mathrm{a}}$ \\
$\mathrm{CH}_{3} \mathrm{OH}$ & $10^{\mathrm{b}}$ & $20^{\mathrm{a}}$ \\
$\mathrm{CH}_{3} \mathrm{CN}$ & $30^{\mathrm{b}}$ & $40^{\mathrm{a}}$ \\
\hline
\end{tabular}

${ }^{a}$ The reaction was not completed within the mentioned period

${ }^{b}$ The reaction was completed in the mentioned time 
UHP has already been used at different temperatures $\left(0^{\circ} \mathrm{C}\right.$, room temperature and reflux $)$ in previous reports [24-25]. The temperature effect in our experiments showed that the oxidation reaction was completed faster at $0^{\circ} \mathrm{C}$ than at other temperatures, due to the high efficiency and stability of UHP at lower temperatures (Table 1). Hence, oxidation of other thiols was carried out in methanol at $0^{\circ} \mathrm{C}$. The results are summarized in Scheme 1 and Table 2.

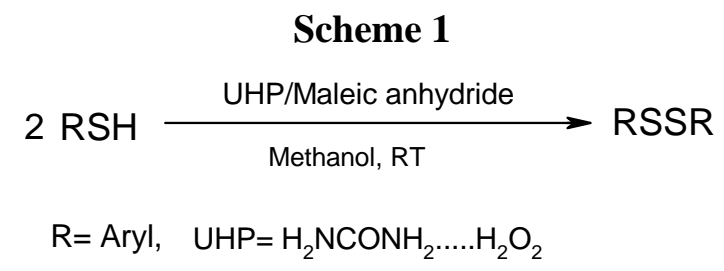

Table 2. Oxidative coupling of thiols using UHP/Maleic anhydride system in methanol at $0^{\circ} \mathrm{C}$

\begin{tabular}{|c|c|c|c|c|c|c|}
\hline Run & Thiols & Disulfides & $\begin{array}{c}\text { Rea } \\
\text { ctio } \\
\text { n } \\
\text { Tim } \\
\text { e } \\
\text { (mi } \\
\text { n.) }\end{array}$ & $\begin{array}{c}\text { Yield }^{\mathrm{a}, \mathrm{b}} \\
(\%)\end{array}$ & $\begin{array}{c}\text { M.P. } \\
\left({ }^{\circ} \mathrm{C}\right) \\
\text { Found }\end{array}$ & $\begin{array}{l}\text { M.P. }\left({ }^{\circ} \mathrm{C}\right) \\
\text { Literature }\end{array}$ \\
\hline 1 & & & 10 & 90 & $144-146$ & $142-145$ [16] \\
\hline 2 & & & 10 & 91 & $43-44$ & $44-45[16]$ \\
\hline 3 & & & 30 & 90 & $72-73$ & $70-71[16]$ \\
\hline 4 & & & 20 & 90 & $69-71$ & $69-70[16]$ \\
\hline 5 & & & 10 & 95 & $90-92$ & $91-93[16]$ \\
\hline 6 & & & 40 & 78 & $55-56$ & $55-57[16]$ \\
\hline 7 & & & 60 & 76 & $133-135$ & $134-136$ [26] \\
\hline 8 & & & 30 & 65 & $177-179$ & $177-180[27]$ \\
\hline 9 & & & 60 & 63 & 202-204 & $202-204$ [28] \\
\hline 10 & $\mathrm{CH}_{3}\left(\mathrm{CH}_{2}\right)_{2} \mathrm{CH}_{2} \mathrm{SH}$ & $\left(\mathrm{CH}_{3}\left(\mathrm{CH}_{2}\right)_{2} \mathrm{CH}_{2} \mathrm{~S}\right)_{2}$ & 18 & 94 & Oil [28] & \\
\hline 11 & $\mathrm{CH}_{3}\left(\mathrm{CH}_{2}\right)_{6} \mathrm{CH}_{2} \mathrm{SH}$ & $\left(\mathrm{CH}_{3}\left(\mathrm{CH}_{2}\right)_{6} \mathrm{CH}_{2} \mathrm{~S}\right)_{2}$ & 20 & 93 & Oil [28] & \\
\hline 12 & n-BuSH & $(\mathrm{n}-\mathrm{BuS})_{2}$ & 20 & 92 & Oil [16] & \\
\hline 13 & $\mathrm{c}-\mathrm{C}_{6} \mathrm{H}_{11} \mathrm{SH}$ & $\left(\mathrm{c}-\mathrm{C}_{6} \mathrm{H}_{11} \mathrm{~S}\right)_{2}$ & 20 & 94 & Oil [16] & \\
\hline
\end{tabular}

${ }^{a}$ Refers to isolated yields; ${ }^{b}$ Identified by MS and ${ }^{1} \mathrm{H}-\mathrm{NMR}$. 
We suggest that oxidation of thiols with urea-hydrogen peroxide proceeds according to Scheme 2 . Based on literature precedents, peroxymaleic acid, formed in situ from the reaction of hydrogen peroxide with maleic anhydride (eq.1) is the active oxidant [24-25]. The active oxygen of the peroxymaleic acid oxidizes RSH to RSOH (eq.2) via I, that reacts with another RSH molecules to produce the disulfide. This is consistent with the fact, as shown in Table 2, that thiols bearing more electron withdrawing substituents, which lead to potentially unstable transition states $\mathbf{I}$ as proposed, are oxidized with more difficulty.

\section{Scheme 2}

1)

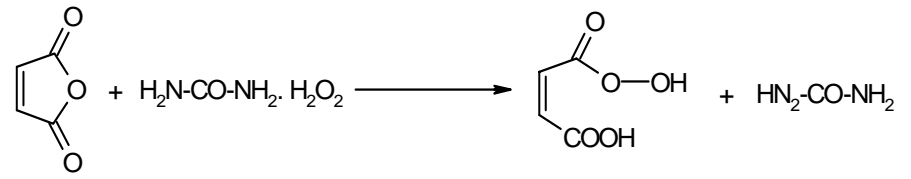

2)

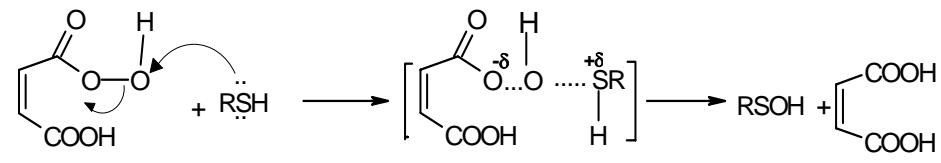

I

3) $\mathrm{RSOH}+\mathrm{RSH} \longrightarrow \mathrm{RSSR}+\mathrm{H}_{2} \mathrm{O}$

\section{Conclusions}

We have described a facile, mild and efficient method for the synthesis of symmetric disulfides with UHP using maleic anhydride as an oxygen transfer agent. Several advantages of this method include high yields of products, relatively short reaction times, low cost, ease of isolation of products, safety and use of a non-toxic oxidant which make this reaction convenient and efficient.

\section{Acknowledgements}

Financial support for this work by Yasouj University is acknowledged. We are also thankful to Mahshahr Petrochemical Company and Mina Varzande for recording ${ }^{1} \mathrm{H}-\mathrm{NMR}$ spectra.

\section{Experimental}

\section{General}

Thiols and maleic anhydride were purchased from Aldrich, Fluka and Merck. UHP was synthesized according to previous report [25]. The reactions were monitored by TLC. The products were isolated and identified by comparison of their physical and spectroscopic data with authentic samples that prepared according to previous methods [16]. IR spectra were recorded on a Jasco-680 FT-IR and the ${ }^{1} \mathrm{H}-\mathrm{NMR}$ spectra were obtained on a Brucker $300 \mathrm{MHz}$ instrument. Mass spectra were recorded on an AMD 604 spectrometer, in EI-mode at $70 \mathrm{eV}$ and FT-mode at $0.005 \mathrm{~V}$. 
Typical procedure for oxidation of 4-methylthiophenol

To a solution of 4-methylthiophenol $(0.1242 \mathrm{~g}, 1 \mathrm{mmol})$ in methanol $(10 \mathrm{~mL})$ at $0^{\circ} \mathrm{C}$, UHP $(0.0941$ $\mathrm{g}, 1 \mathrm{mmol})$ and maleic anhydride $(0.0980 \mathrm{~g}, 1 \mathrm{mmol})$ were added. The progress of the oxidation was followed by TLC (n-hexane-ethyl acetate, 7:3). After completion of the reaction, the solvent was evaporated under vacuum at room temperature and then $n$-hexane/chloroform $(9: 1,10 \mathrm{~mL})$ was added and the mixture was filtered on silica gel. The solvent was removed under vacuum and 4,4-dimethyldiphenyl disulfide was obtained as white crystals $\left(0.2217 \mathrm{~g}, 90 \%\right.$ yield); m.p. $45-47^{\circ} \mathrm{C}$ (Ref. [16] 44$\left.45^{\circ} \mathrm{C}\right) ;{ }^{1} \mathrm{H}-\mathrm{NMR}\left(\mathrm{CDCl}_{3}\right): \delta / \mathrm{ppm}: 7.50(\mathrm{~d}, 4 \mathrm{H}), 7.20(\mathrm{~d}, 4 \mathrm{H}), 2.46\left(\mathrm{~S}, 6 \mathrm{H}, 2 \mathrm{CH}_{3}\right) ; \mathrm{MS}(70 \mathrm{eV}): \mathrm{m} / \mathrm{z}$ : $246\left(\mathrm{M}^{+}\right)$.

\section{References and Notes}

1. (a) Drabowicz, J.; Mikolajczyk, M. Synthesis 1980, 32; (b) Jocelyn, P.C. In Biochemistry of the SH Group; Academic Press: London, New York, 1972.

2. (a) Wolman, Y. The Chemistry of the Thiol Groups, Patai, S. ed.; John Wiley \& Sons: London, 1974; Chapter 14; (b) Bodanszky, M. Principles of Peptide Synthesis; Springer-Verlag: Berlin, 1984; Chapter 4.

3. (a) Trost, B.; Salzmann, T. N. J. Am. Chem. Soc. 1973, 95, 6840; (b) Seebach, D.; Teschner, M. Tetrahedron Lett. 1973, 5113.

4. (a) Zoretic, P. A.; Soja, P. J. Org. Chem. 1976, 41, 3587; (b) Gassman, P. G.; Balchunis, R. J. J. Org. Chem. 1977, 42, 3236.

5. Kharasch, N.; Arora, A. S. Phosphorus Sulfur Silicon 1976, 2, 1.

6. Riordan, J. F.; Sokovsky, M.; Vallee, B. L. J. Am. Chem. Soc. 1966, 88, 4105.

7. Kosower, E. M.; Kosower, N. S. Nature 1969, 224, 117.

8. (a) Wallace, T. T. J. Am. Chem. Soc. 1964, 86, 2018; (b) Wallace, T. T.; Wein, H. A. Chem. Ind. (London) 1966, 1558 .

9. Small, D. L.; Bailey, J. H.; Cavallito, G. J. J. Am. Chem. Soc. 1947, 69, 1711.

10. Chistensen, W. L.; Heacock, D. J. Synthesis 1978, 50.

11. Evans, B. J.; Doi, J. T.; Musker, W. K. J. Org. Chem. 1990, 55, 2337.

12. Noureldin, N. A.; Caldwell, M.; Hendry, J.; Lee, D. G. Synthesis 1998, 1587.

13. (a) Aida,T.; Akasaka,T.; Furukawa, N.; Oae, S. Bull. Chem. Soc. Jpn. 1976, 49, 1441; (b) Fristad, W. E.; Peterson, J. R. Synth. Commun. 1985, 15, 1.

14. Mckillop, A.; Koyuncu, D. Tetrahedron Lett. 1990, 31, 5007.

15. Leite, S. L. S.; Pardini, V. L.; Viertler, H. Synth. Commun. 1990, 20, 393.

16. Khodaei, M. M.; Mohammadpoor-Baltork, I.; Nikoofar, K. Bull. Kor. Chem. Soc. 2003, 24, 885.

17. Kudryavtseva, E. V.; Sidorova, M. V.; Ovchinnikov, M. V.; Besfpalova, Z. D. J. Peptide Sci. 2000 6, 208.

18. Hajipour, A. R.; Ruoho, A. E. Phosphorus Sulfur Silicon 2003, 178, 1277.

19. Ballini, R.; Marcantoni, E.; Petrini, M. Tetrahedron Lett. 1992, 33, 4835.

20. (a) Astodillo, L.; Galindo, A.; Gonzalez, A. G.; Mansilla, H. Heterocycles 1993, 36, 1075; (b) Uchida, T.; Katsuki, T. Tetrahedron Lett. 2001, 42, 6911. 
21. Balicki, R. Synth. Commun. 1999, 29, 2235.

22. Heaney, H.; Newbold, A. J. Tetrahedron Lett. 2001, 42, 6607.

23. Perez, J. M.; Lopez-Alvardo,P.; Pascual-Alfonso, E.; Avendano, C.; Menendez, J. C. Tetrahedron 2000, 56, 4575.

24. (a) Pietikainen, P. J. Mol. Cat. A: Chem. 2001, 165, 73; (b) Kureshy, R. I.; Khan, N. H.; Abdi,S. H. R.; Patel, S. T.; Jasra, R. V. Tetrahedron: Asymmetr. 2001, 12, 433.

25. Damavandi, J.; Karami, A. B.; Zolfigol, M. A. Synlett 2002, 933 and references therein.

26. Chemicals and Reagents 2005-2007; Merck KGaA: Darmstadt, Germany; p. 382.

27. Jensen, G. B.; Smith, G.; Sagatys, D. S.; Healyb, P. C.; White, J. M. Acta Cryst. 2004, E60, 2438.

28. Khazaei, A.; Zolfigol, M. A.; Rostami, A. Synthesis 2004, 2959.

Sample Availability: Available from the authors.

(C) 2005 by MDPI (http:www.mdpi.org). Reproduction is permitted for noncommercial purposes. 